\title{
Design of the supply for the fishing cooperative society of Tamiahua, Veracruz
}

\section{Diseño de la cadena de suministro para la sociedad cooperativa pesquera de Tamiahua, Veracruz.}

VALDEZ-PÉREZ, María de los Ángeles $\dagger^{*}$, BENITEZ-LÓPEZ, Guillermo and CRUZ-CHAVEZ, Margarita

Instituto Tecnológico Superior de Naranjos. Ingeniería Industrial, México.

Instituto Tecnológico Superior de Naranjos. Ingeniería en Logística, México.

ID $1^{\text {st }}$ Author: Maria de los Ángeles, Valdez-Pérez / ORC ID: 0000-0002-0242-0055, CVU CONACYT ID: 167124

ID $1^{\text {st }}$ Co-author: Guillermo, Benitez-López / ORC ID: 0000-0003-2006-9876, CVU CONACYT ID: 468967

ID $2^{\text {nd }}$ Co-author: Margarita, Cruz-Chavez / ORC ID: 0000-0001-7394-7957, CVU CONACYT ID: 774907

DOI: $10.35429 / J M P C .2021 .20 .7 .6 .16$

Received: July 15, 2021 Accepted: December 30, 2021

\begin{abstract}
This is article is oriented to the design of a supply chain that is essential for a better distribution of products, mainly in the fishing sector, giving better customer service. The main objective of the fishing cooperatives is to supply fish food products obtained from the Tamiahua lagoon (Area Number 2) to the local wineries and nearby communities in a timely manner. A study of the current conditions was carried out, implemented tools of the Ishikawa diagram and processes to determine the supply chain. According to the techniques used, it was determined that attention must be paid to this sector due to the decrease in production compared to previous years, as well as the decrease in some species that have been presented to date. In addittion, the design of the supply chain was determined in order to guarantee the distribution of the product in the fishing sector. The cooperative must take into account the supply chain because it has to ensure the sale and distribution of the fish.
\end{abstract}

\begin{abstract}
Resumen
Este articulo está orientado al diseño de una cadena de suministro que son indispensable para una mejor distribución de los productos principalmente en el sector pesquero dando un mejor servicio al cliente. Las Cooperativas pesqueras tiene como objetivo prioritario abastecer con productos alimenticios pesqueros obtenidos de la laguna de Tamiahua (Área ${ }^{\circ} 2$ ) a las bodegas de la localidad y las comunidades cercanas en tiempo y forma. Se realizó un estudio de las condiciones actuales, implementado herramientas de, diagrama de Ishikawa y de procesos con el fin de determinar la cadena de suministro. De acuerdo con las técnicas empleadas se determinó que se tienen que fijar la atención en este sector debido a la disminución de producción en comparación de años anteriores asimismo se apreció la disminución de algunas especies que se han presentado hasta la actualidad. Sé determinó el diseño de la cadena de suministro con el fin de garantizar la distribución del producto en el sector pesquero. La cooperativa debe tener en cuenta la cadena de suministro para garantizar la venta y distribución del pescado.
\end{abstract}

Cadena de suministro, Sector pesquero, Cooperativas

\footnotetext{
* Correspondence of the Author (Email: angeles.valdez@itsna.edu.mx)

$\dagger$ Researcher contributing as first author.
} 


\section{Introduction}

Logistcs is an integrated process with a company, associated with the good management and admistration of the different flows that compose it (capital, goods, services, people, etc.) whose development impacts on the perfomance of organizations, favorig their competitiveness. The important thing for a company is not only to produce a good with competitive costs, but to achieve through logistics make available to the costumer the products and services they demand at the exact time and in the right place in ideal conditions and at an optimal cost with tha porpuse of satisfying the requirements of the supply chain effectively and efficiently as posible.

The welfare levels of cooperative societies in Mexico are substantially lower than the national averages according to CONEVAL (2017). In Veracruz, a total of $22232901 \mathrm{~kg}(9 \%)$ is estimated, equivalent to 34497311.2187 pesos (2\%) of productive participation in species and its economic valuation at the state level.

The municipality of Tamiahua, Veracruz is located in the upper Huasteca of the state with a lagoon 85 kilometers long, it is shallow and it provides species that are cmmercialized through local cooperative societies, such as: shrimp, crab, clam, oyster, fish: bighead, Shell, dogfish, corvina, chavela, chochomite, churro, lebrancha, crappie, black, snapper, robalo, bream.

Currently there has been a decrease in fishing by fishermen and also by the lagoon because there is no supply chain as such that helps to have a clear visión of the activity carried out. Therefore, this article aims to desing a supply chain for the cooperative society, wich goes from the first link that involves how the raw material is acquired, to the last link in the chain that includes the entire distribution of the marketed producto and can generate value in the services it provides.

This articule is written in sections in wich the location of the place, objective, importance, methodology used, results, acnowledgments, conclusions, and references used.

\section{Location}

The Tamiahua Lagoon is considered one of the lagoons with the greatest diversity of fish species, of which approximately 120 are reported (Gordillo-Morales and Cruz-Paredes, 2005). These characteristics give it the third place nationally in diversity of habitats and variety of species. It is located in the coastal plains of the north of the state of Veracruz, between $20^{\circ} 57^{\prime} 36^{\prime \prime}$ North latitude and $97^{\circ} 18$ '41' 'West longitude; it is shared by the municipalities of Ozuluama, Tamalín, Tamiahua, Tampico Alto and Tuxpan. The most important and closest towns are Tamiahua, Naranjos, Tuxpan and Tampico; the latter belongs to the state of Tamaulipas. The lagoon has a length (major axis) of $85 \mathrm{~km}$ and a maximum width (minor axis) of $25 \mathrm{~km}$. The Tamiahua Lagoon is located the discharges of the Tuxpan and Tamiahua rivers, the Pánuco river, as well as the Pueblo Viejo Lagoon and the Tampamachoco Lagoon. (Álvarez, 2000).

\section{Objective}

This article aims to design a supply chain in order to generate value in the service it provides.

The specific objectives are:

Carry out a diagnosis of the cooperative society to identify its problems.

Analyze the information collected in the cooperative.

Identify the areas that make up the structure of the Fisheries Cooperative Society

Carry out the design of the supply chain of the fishing cooperative society.

\section{Logistics and supply chain}

Logistics is defined as the set of means and methods that allow to carry out the organization of a company or a service. Therefore, it is considered that the logistical implication must be integrated in all areas of the company. 
According to Jiménez (2002), he mentions that the supply chain is made up of suppliers, warehouses, the line that is producing, the different channels through which it travels, sales to wholesalers, sales to retailers and even the last step where it reaches the end customer's hands. The following order is considered: Raw materials, Production, Transport and logistics, Agencies or branches, Storage, Sales, Billing, Distribution and Delivery.

The supply chain is a process that encompasses all movements of a product. This must be one of the essential parts for the proper functioning of the flows of a chain since it depends on it to successfully achieve the general objectives of a company. It is integrated into 3 fundamental parts: Supply, Production and Distribution.

The Supply is the activity thata is carried out to satisfy the consumption needs of an economic structure.

Production refers to obtaining products or services. Distribution is the activity carried out from when the product has been produced by the manufacturer until it has been purchased. This concept is very important to guarantee the sales of a product since it is not enough to have a quality article and even a competitive price.

Supply chain management consists of the alignment and synchronization of all logistics processes, as well as suppliers, producers, distributors and customers (Gómez 2019).

According to Manrique (2019), the first phase is the supply of materials, resources and / or supplies in order to start productive work. In phase 2 , each process is particular according to its line of business and in the final phase it allows the guarantee of sales as well as income, allowing positioning in the markets.

\section{Cooperative and types of cooperatives}

The cooperative society is a form of social organization made up of individuals based on common interests and the principles of solidarity, self-help and mutual help, with the purpose of satisfying individual and collective needs, through the performance of economic activities of production, distribution and consumption of goods and services. (General Law of Cooperative Societies, 2018)

\section{Types of cooperatives}

Cooperative systems are named by the following:

I.- Of consumers of goods and / or services,

II.- Of producers of goods and / or services,

III.- Savings and loans.

\section{Cooperative society categories}

Cooperative systems are named by the following:

I.- Of consumers of goods and / or services,

II.- Of producers of goods and / or services,

III.- Savings and loans.

\section{Cooperative society categories}

Cooperative societies are categorized:

I.- Ordinary,

II.- State participation.

For this purpose, the State may grant or administer goods or services to cooperative societies, under the terms indicated by the respective laws. (General Law of Cooperative Societies, 2018)

\section{Types of fishing}

Álvarez (2009) classifies the types of fishing according to the use of the techniques and implements that are used to carry it out, or according to the type of species to which fishing is focused, among other ways of classification. The fishermen of Tamiahua carry out the following types of fishing due to the different species found.

- Gill nets or gillnets: Used to capture Mugil curema. (García, 1981).

Chinchorro type nets: It is a trawl net, limited by the upper rope with floats and the lower rope with lead weights. Its two wings end in sticks or rudders and ropes to pull it. It is used to capture snook. (AriasArias, 1988).

VALDEZ-PÉREZ, María de los Ángeles, BENITEZLÓPEZ, Guillermo and CRUZ-CHAVEZ, Margarita. Design of the supply for the fishing cooperative society of Tamiahua, Veracruz. Journal of Microfinance Planning and Control. 2021 
- Atarrayas: They are used to catch small fish. (INP, 2000.).

Glasses or rake: It has the shape of a scissor or clamp, made of wood with nails, it is used to capture oysters (D.O.F., 2006)

- Charangas It is used for the fishing of different species of shrimp (D.O.F., 1997)

Jaibera ring or pot: It consists of a galvanized wire ring and is used to catch crabs. (Arzate, 1991)

- Jaibera trap: Cubic in shape, made of a hexagonal mesh of galvanized wire. (Oesterling, 1984).

Whatson (2006) makes a mapping through a database which refers to the annual percentage of catch, presenting eight types of catch out of a total of 42 associated with global catches, of which it mentions: trap, dredge, hook and line, gilnet, bottom trawl, mindwater trawl, seine and others. In this graph it can be observed that fishing has increased and consequently also the decrease of species. (figure 1).

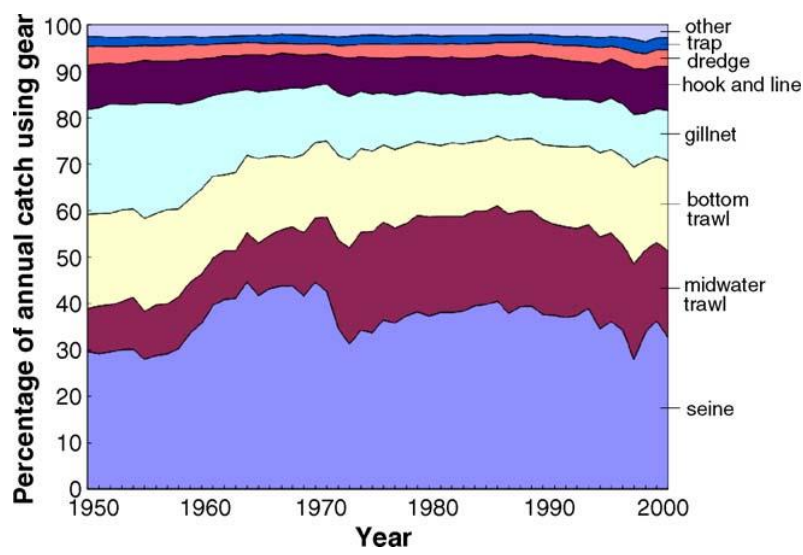

Figure 1 Percentage of anual catch Source: Watson (2006)

\section{Types of tools}

Various types of tools are used in fishing, which are mentioned in Table 1 below.

\begin{tabular}{|l|l|}
\hline \multicolumn{1}{|c|}{ Tool type } & \multicolumn{1}{c|}{ Description } \\
\hline boat & $\begin{array}{l}\text { It is a small motor boat. } \\
\text { top or float line and to a sinker line of } \\
\text { sinkers, which is used to catch fish. }\end{array}$ \\
\hline nets & $\begin{array}{l}\text { kitchen utensil used as a filter or food } \\
\text { drain. }\end{array}$ \\
\hline strainers & $\begin{array}{l}\text { Reusable packaging for the transport } \\
\text { and storage of certain products. }\end{array}$ \\
\hline plastic box & $\begin{array}{l}\text { large containers to store the product } \\
\text { with water and ice before being stored } \\
\text { or distributed. }\end{array}$ \\
\hline containers & $\begin{array}{l}\text { An appliance for freezing food and } \\
\text { keeping it frozen. }\end{array}$ \\
\hline freezer & $\begin{array}{l}\text { Shallow container, usually rectangular } \\
\text { in shape, made of glass, plastic, } \\
\text { porcelain, etc. }\end{array}$ \\
\hline $\begin{array}{l}\text { Wray } \\
\text { machine }\end{array}$ & $\begin{array}{l}\text { Instrument to measure weights, } \\
\text { generally large, consisting of a } \\
\text { platform where you place what you } \\
\text { want to weigh, a system of levers that } \\
\text { transmits the weight to an arm that is } \\
\text { balanced with a weight, and an } \\
\text { indicator that marks the weight. }\end{array}$ \\
\hline atarrayas & $\begin{array}{l}\text { A net-shaped instrument used to } \\
\text { remove shrimp from the water. }\end{array}$ \\
\hline spoon & $\begin{array}{l}\text { Furniture formed by a horizontal } \\
\text { tabletop, supported by one or more } \\
\text { feet, with the convenient height to be } \\
\text { able to carry out any activity on it or } \\
\text { leave things on top } \\
\text { Round net for fishing in shallow water. }\end{array}$ \\
\hline
\end{tabular}

Table 1 Types of fishing tools

Source: Self-made

\section{Methodology to be developed}

A documentary investigation of historical data of the cooperatives was carried out in order to know the productivity and species that existed in previous years because the decrease in fishing production has been reflected in recent years in the Tamiahua lagoon, municipality of Tamiahua. It was investigated in the section fishing production for 4 months in the shrimp and scales species. An Ishikawa diagram was also made to diagnose the possible causes that are causing the problem of low fish production and finally a supply chain of the cooperative's fish production was made. The fishing periods are limited to certain restrictions for reasons of closure in accordance with the fishing regulations defined by the corresponding authorities. 


\section{Results}

In the Tamiahua lagoon there are various species such as: shrimp, crab, mullet, liet, Ostion crassostrea virginica, white and black snook, trout, bream, snapper, lebrancha, mojarra, chucumite, stray. Next, the closed periods that occur in order to guarantee fishing throughout the year are mentioned.

\begin{tabular}{|c|c|c|c|}
\hline Species & Zone & $\begin{array}{l}\text { Start of } \\
\text { fishing } \\
\text { ban }\end{array}$ & $\begin{array}{l}\text { End of } \\
\text { fishing } \\
\text { ban }\end{array}$ \\
\hline Shrimp & $\begin{array}{l}\text { Gulf of Mexico } \\
\text { and Caribbean } \\
\text { Sea (zone 2) } \\
\text { estuarine lagoon } \\
\text { systems from } \\
\text { Tamaulipas to } \\
\text { the mouth of the } \\
\text { Coatzacoalcos } \\
\text { river, Ver. }\end{array}$ & May 27th & $\begin{array}{l}\text { September } \\
\text { 30th }\end{array}$ \\
\hline Crayfish & $\begin{array}{ll}\text { Coastlines } & \text { of } \\
\text { the Gulf of } \\
\text { Mexico }\end{array}$ & May 1 & June 30th \\
\hline $\begin{array}{l}\text { Mullet fish } \\
\text { (Mugil } \\
\text { cephalus) }\end{array}$ & $\begin{array}{l}\text { Gulf of Mexico } \\
\text { (zone 3) coastal } \\
\text { waters of } \\
\text { Tamaulipas and } \\
\text { in the northern } \\
\text { zone of } \\
\text { Veracruz. }\end{array}$ & $\begin{array}{c}\text { December } \\
1 \\
\text { February } \\
01\end{array}$ & $\begin{array}{c}\text { December } \\
31 \text { st } \\
\text { February } \\
\text { 28th }\end{array}$ \\
\hline $\begin{array}{l}\text { Silver mullet } \\
\text { (mugil } \\
\text { curema) }\end{array}$ & $\begin{array}{l}\text { Gulf of Mexico } \\
\text { (zone 3) coastal } \\
\text { waters of } \\
\text { Tamaulipas and } \\
\text { in the northern } \\
\text { zone of } \\
\text { Veracruz }\end{array}$ & $\begin{array}{c}\text { December } \\
1 \\
\text { February } \\
01\end{array}$ & $\begin{array}{c}\text { December } \\
\text { 31st } \\
\text { February } \\
\text { 28th }\end{array}$ \\
\hline $\begin{array}{l}\text { Oyster } \\
\text { (crassostrea } \\
\text { virginica) }\end{array}$ & $\begin{array}{l}\text { Lagoon systems } \\
\text { of the Gulf of } \\
\text { Mexico }\end{array}$ & $\begin{array}{c}\text { April 15 } \\
\text { September } \\
15\end{array}$ & $\begin{array}{c}\text { may } 31 \\
31 \\
\text { October }\end{array}$ \\
\hline $\begin{array}{lr}\text { White } & \text { snook } \\
\text { and } & \text { black } \\
\text { snook } & \end{array}$ & $\begin{array}{l}\text { From the barra } \\
\text { de chachalacas, } \\
\text { Veracruz to } \\
\text { barra Tonalá } \\
\text { (zone 2) }\end{array}$ & July, 01 & $\begin{array}{c}\text { August } \\
\text { 15th }\end{array}$ \\
\hline trout & $\begin{array}{l}\text { From the barra } \\
\text { de chachalacas, } \\
\text { Veracruz to } \\
\text { barra Tonalá } \\
\text { (zone 2) }\end{array}$ & $\begin{array}{c}\text { October } \\
15 \text { th }\end{array}$ & $\begin{array}{c}\text { February } \\
15\end{array}$ \\
\hline sargo & $\begin{array}{l}\text { From the barra } \\
\text { de chachalacas, } \\
\text { Veracruz to } \\
\text { barra Tonalá } \\
\text { (zone 2) }\end{array}$ & July, 01 & $\begin{array}{c}\text { August } \\
\text { 15th }\end{array}$ \\
\hline snapper & $\begin{array}{l}\text { Lagoon systems } \\
\text { of the Gulf of } \\
\text { Mexico. }\end{array}$ & & \\
\hline $\begin{array}{l}\text { Lebrancha } \\
\text { (mugil } \\
\text { curema } \\
\text { valenciennes) }\end{array}$ & $\begin{array}{l}\text { Gulf of Mexico } \\
\text { (zone 3) coastal } \\
\text { waters of } \\
\text { Tamaulipas and } \\
\text { in the northern } \\
\text { zone of } \\
\text { Veracruz. }\end{array}$ & $\begin{array}{c}\text { December } \\
1\end{array}$ & $\begin{array}{c}\text { December } \\
31 \mathrm{st}\end{array}$ \\
\hline Mojarra & Lagoon systems & $\begin{array}{c}\text { September } \\
15\end{array}$ & $\begin{array}{c}31 \\
\text { October }\end{array}$ \\
\hline
\end{tabular}

\begin{tabular}{|c|c|c|c|}
\hline Chucumite & $\begin{array}{l}\text { Gulf of Mexico } \\
\text { and Caribbean } \\
\text { Sea (zone 2) } \\
\text { estuarine lagoon } \\
\text { systems from } \\
\text { Tamaulipas to } \\
\text { the mouth of the } \\
\text { Coatzacoalcos } \\
\text { river, See }\end{array}$ & $\begin{array}{c}\text { December } \\
1\end{array}$ & $\begin{array}{c}\text { December } \\
31 \mathrm{st}\end{array}$ \\
\hline extraviado & $\begin{array}{l}\text { Gulf of Mexico } \\
\text { (zone 3) coastal } \\
\text { waters of } \\
\text { Tamaulipas and } \\
\text { in the northern } \\
\text { zone of } \\
\text { Veracruz. }\end{array}$ & $\begin{array}{l}\text { all season } \\
\text { of the year }\end{array}$ & $\begin{array}{l}\text { all season } \\
\text { of the year }\end{array}$ \\
\hline
\end{tabular}

Table 2 Closed periods

Source: Coopertaive "Pescadores de Tamiahua"

\section{Historical data of species in the Tamiahua Lagoon}

Relevant data has been reported regarding the volume and production from 1998 to 2005 , by species, by production value. Of which it was found that from 1998 to 2005 the volume of shrimp has remained at an approximate of 500 tons per year. The volume of scale has decreased from approximately 11,000 tons to 3,000 tons in 2005. Regarding the economic value, the scale has fallen from 63 million pesos to 25 million pesos and shrimp from 15 million pesos to 32 million pesos. pesos. (Álvarez, 2009).

\section{Causes of decreased production in fishing}

The Ishikawa diagram made it possible to diagnose the possible causes that have affected the decrease in production corresponding to previous years.

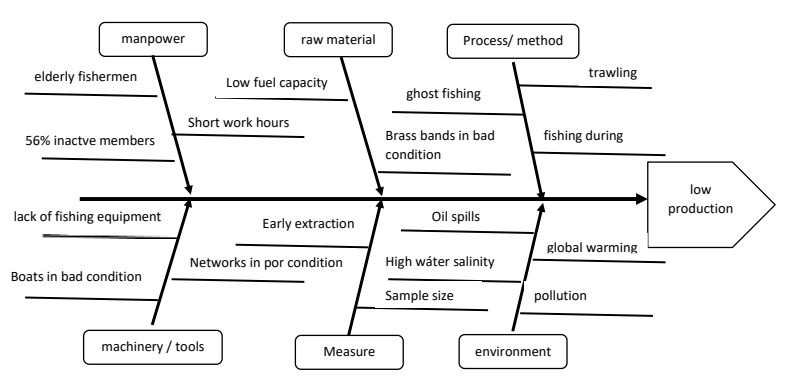

Figure 2 Ishikawa diagram on the causas that have impacte don the production in the Tamiahua Lagoon Source: self-made

As shown in figure 2, the Fishermen's lack of equipment, the number of active partners in this activity, the contamination of the lagoon, as well as the early extraction has caused the decrease in the production of extraction of species in the lagoon of Tamiahua.

VALDEZ-PÉREZ, María de los Ángeles, BENITEZLÓPEZ, Guillermo and CRUZ-CHAVEZ, Margarita. Design of the supply for the fishing cooperative society of Tamiahua, Veracruz. Journal of Microfinance Planning and Control. 2021 
Below are the formats used by the cooperative to control the extraction of fishing and guarantee the existence of the species in the future.

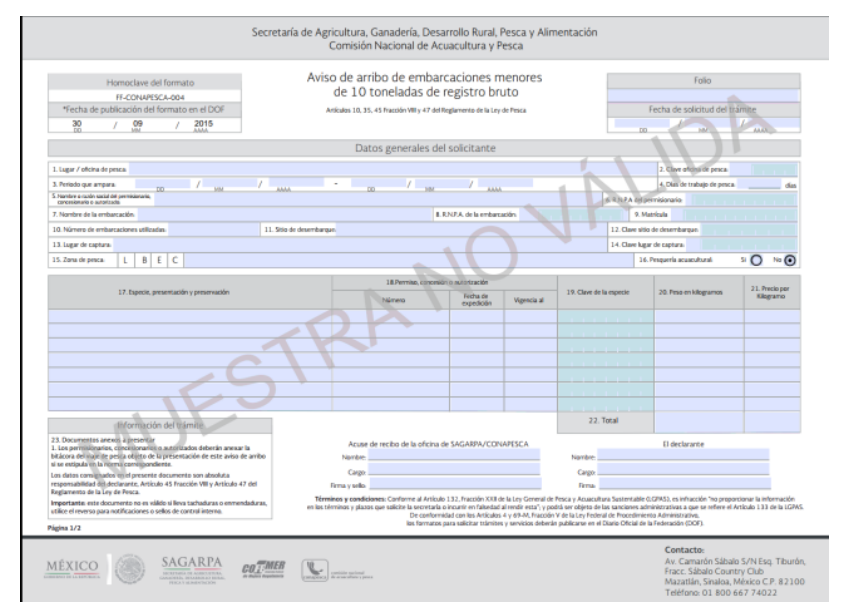

Figure 3 Notice of arrival of vessels under 10 gross registered tons.

Source:http://www.dof.gob.mx/nota_detalle_popup.php? codigo $=5409964$

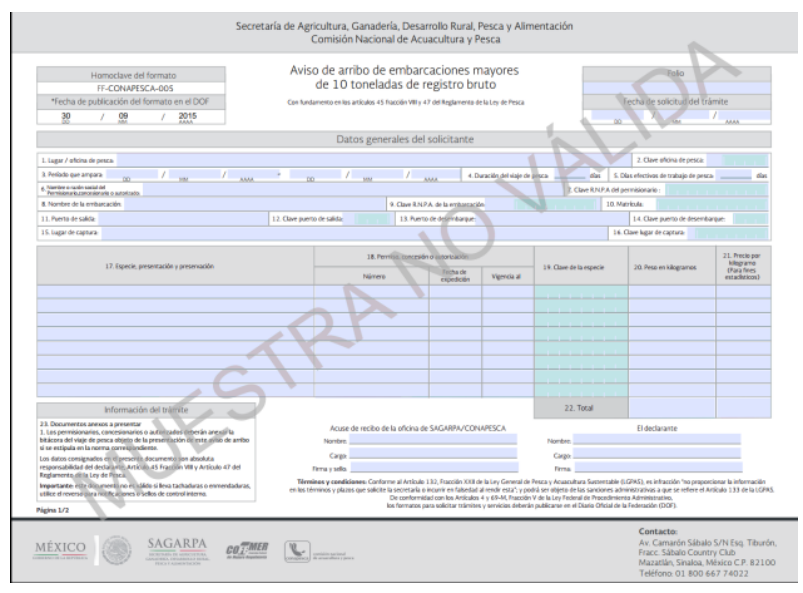

Figure 4 Notice of arrival of vessels greater than 10 gross tons

Source:http://www.dof.gob.mx/nota_detalle_popup.php? codigo $=5409964$

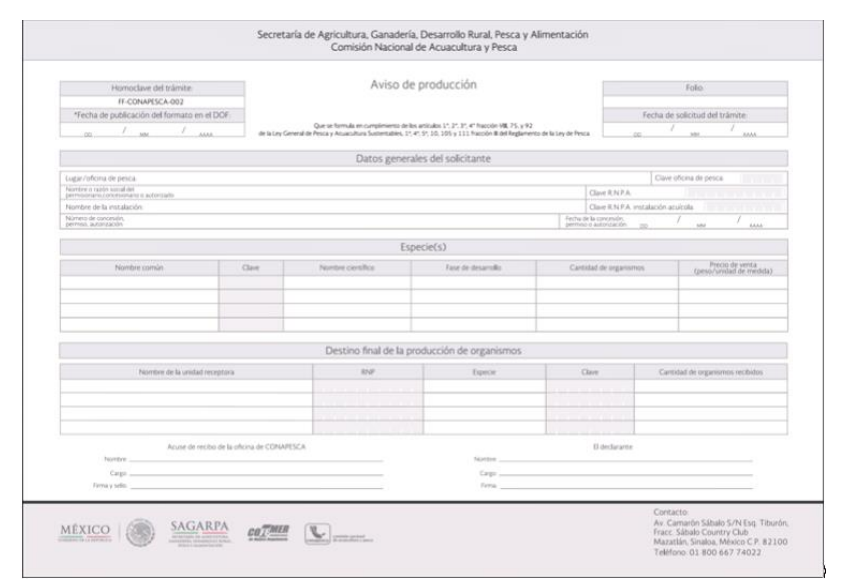

Figure 5 Production notice

Source:http://www.dof.gob.mx/nota_detalle_popup.php? codigo $=5409964$

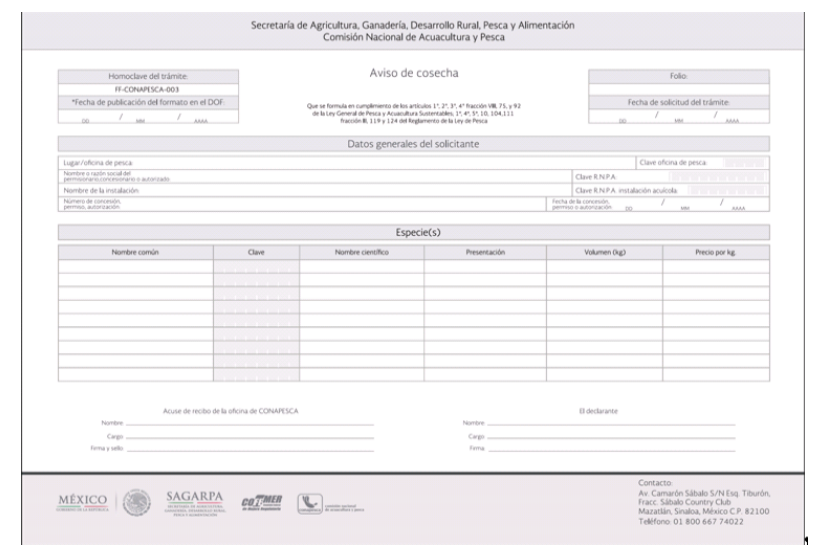

Figure 6 Harvest notice

Source:http://www.dof.gob.mx/nota_detalle_popup.php? codigo $=5409964$

The arrivals in figure 3 and 4 are made with the data collected weekly through the checkbooks that the sales manager records daily. In this way, an official record is delivered to the Conapesca offices.

The production and harvest notices, unlike the arrivals, have a section in the document where it requires mentioning the scientific name of the species harvested and produced. These documents are delivered when you want to report any of the marine species. (Figure 5,6).

For the realization of graph 1, the production of scales (various species of fish) and shrimp was monitored within the cooperative in a period of 4 months. From which it can be shown that shrimp production is higher with respect to fish fishing, but it is lower according to the fishing of previous years; This means that in effect the causes shown above in the Ishikawa diagram have deteriorated the fishing in the Lagoon. 
Production August- December 2019

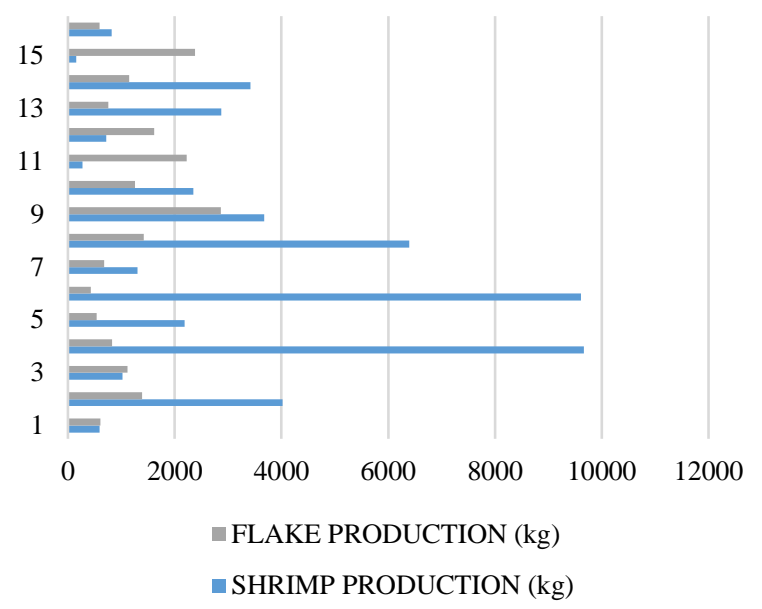

Graphic 1 Scale and shrimp production (AugustDecember 2019)

Source: Self-made

\section{Supply chain design}

Next, the supply chain is described in order to recognize the elements that make it up in the fish production of the cooperative studied.

\section{Partners - Cooperativa:}

Currently 350 members are registered, of which only 150 remain active producing for the Cooperative Society. From an early hour, fishermen go to the banks also called "charrangas" located within the concession that they have assigned within the lagoon for the extraction of shrimp and scale (fish). When extracting the species they verify that they have the minimum size, those that do not have this requirement are returned to the lagoon. Those that do comply with these specifications are stored in ice-filled refrigerators for better conservation, later they are delivered to the cooperative where the production is weighed and a receipt is given of the daily production.

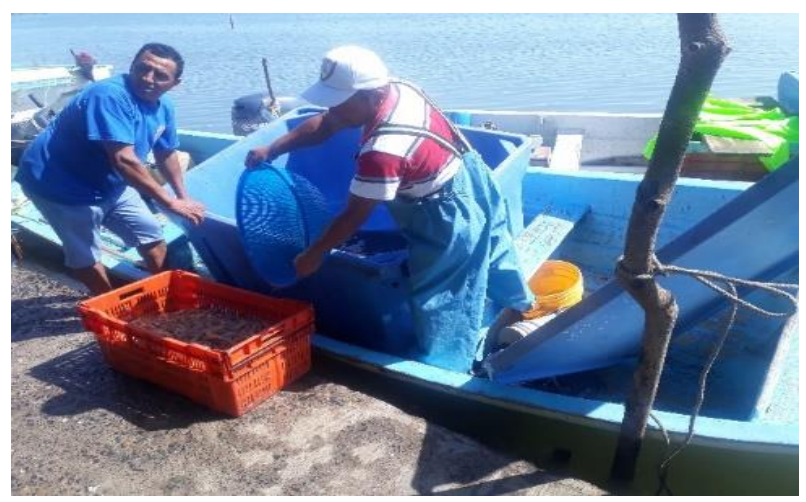

Figure 7 Delivery of production to the cooperative Source: self-made

\section{- Cooperativa - distributors}

The Cooperative Society has its regular customers who day after day go safely to the wholesale purchase of shrimp and fish, most of the distributors are mainly local and some are from cities near Tamiahua. They come mainly in refrigerated vans and some with large refrigerators where they deposit the product with ice. The distributors have greater storage capacity than the Cooperativa itself, therefore the product can remain in good condition for much longer periods of time in the freezer.

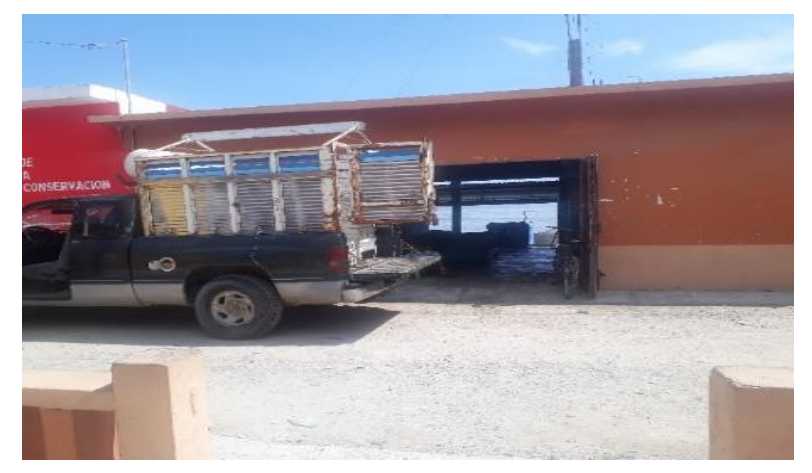

Figure 8 Transports for distribution Source: self-made

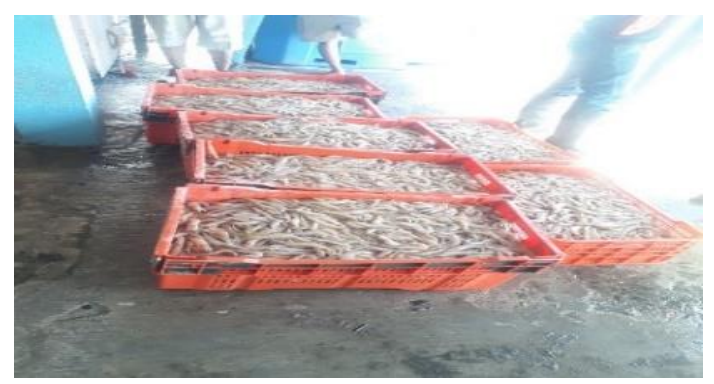

Figure 9 Shrimp delivery to distributors Source: self-made

- Distributors - sellers

Distributors have a great capacity to purchase such products, which is why they also have warehouses (figure 10) equipped with large-capacity refrigerators for proper storage. They are responsible for maintaining the preservation conditions of the fish in optimal conditions for a longer time, therefore the ice must comply with the physical, chemical and microbiological parameters described in the regulation of the quality of water for human consumption (NOM-201-SSA1 -2015). Distributors also have their clients (local vendors) who come to buy fish and shrimp, but in less quantity in this way they supply their premises and businesses individually. 


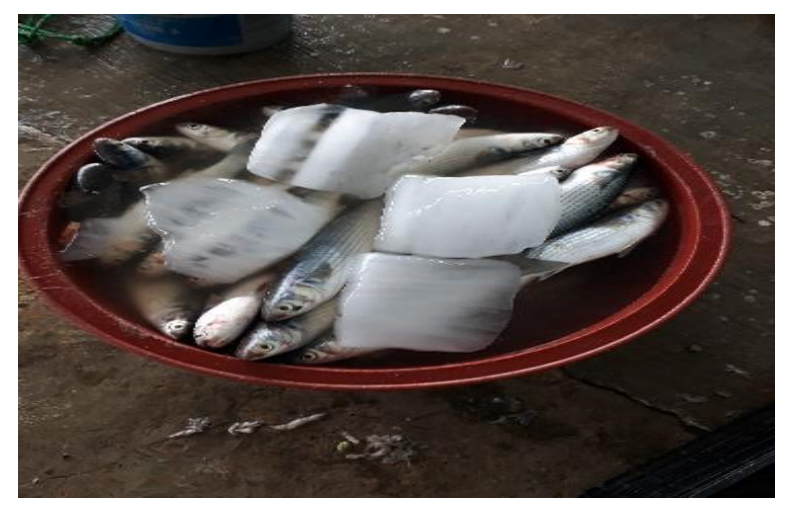

Figure 10 Local seafood wineries Source: self-made

\section{- Local sellers to clients}

Sellers are in charge of distributing the product to final consumers through small stalls, which as a goal they purchase the product in small quantities, but this part of the supply chain is very important, since they are the people who actually use it. and they consume the product. The final consumer differs significantly from the customer, who can buy the product, but not necessarily consume it. (figure 11 and 12)

The main final consumers are:

- Customers of restaurants or snack bars.

- $\quad$ Tourists.

- $\quad$ Local families.

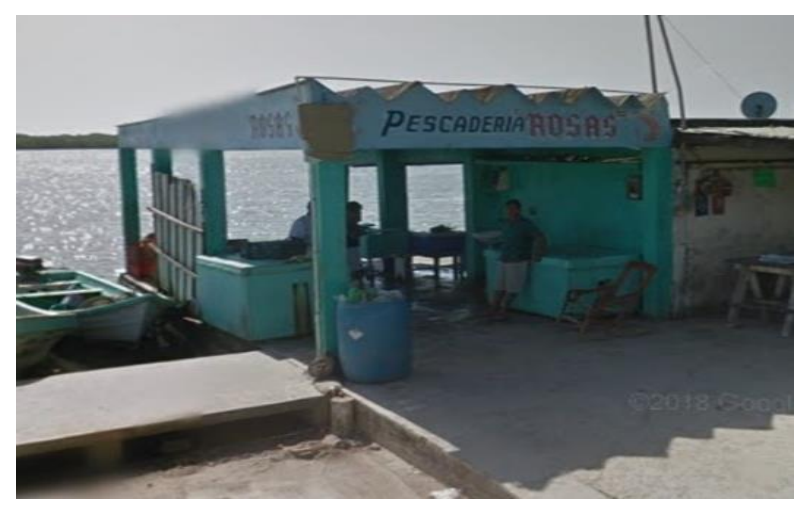

Figure 11 Container where the fish are exposed Source: self-made

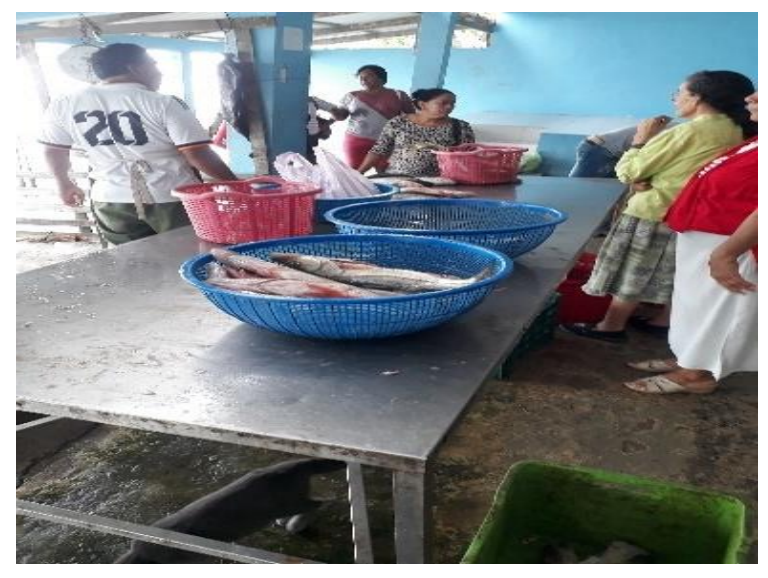

Figure 12 Business customers

Source: self-made

\section{Synchronization of each member of the supply chain}

For proper communication between the elements that make up the supply chain, a report was made of the different activities carried out by the links in the chain, in this way describing in detail the function that each one of them performs with their corresponding activities.

The first link in the chain are the registered partners that make up the cooperative society.

Second link is the receipt and registration of the products that arrive daily at the cooperative. A receipt is drawn up which the fishermen later collect.

Third link are the distributors of the merchandise in charge of acquiring the product in wholesale, they have warehouses equipped for the conservation of these foods.

Fourth link are the businesses that turn to the distributors for the purchase of fish and shrimp to supply their businesses within or outside the city. Business owners often go to distributors on a daily basis.

Fifth link are the clients or final consumer who purchase the product through the different typical dishes of the area, these are sold in different restaurants, hotels, street vendors.

Registered members: they are in charge of extracting the shrimp and scale species (smooth, snook, lebrancha, sargo, etc.) inside or outside the lagoon in this way to provide the cooperative with its daily production. 
Cooperativa Pescadores de Tamiahua: in charge of carrying out the inputs and outputs of the production that arrives daily, performs and records the weight (kilos) in checkbooks and delivers receipts to the fishermen that they later collect as payment for their production contributed to the cooperative.

Subsequently, the Cooperative performs the weekly record of production and sale in arrivals that are delivered to the CONAPESCA offices.

Distributors: responsible for acquiring and buying the vast majority of the production since they have more facility to sell these products within the locality or outside of it. In addition, they have a greater capacity to store and refrigerate these products.

Local sellers: they buy in less quantity since their scope of sale is more limited. In addition, they do not have a large storage capacity. They usually sell retail, but unlike distributors they have a greater capacity to display these products and thus sell them to retailers.

Customers: they are a great link in the supply chain since they are the ones who actually consume the product, in this way a correct operation is obtained from the extraction of the product to its final consumer.

The supply chain synchronization with each of the aforementioned members is shown by diagram below.

\section{Determination of the supply chain}

The design of the supply chain was carried out taking into account the different elements that comprise it mentioned above, in such a way that it is possible to contemplate what the activities carried out in this community consist of within the cooperative "Pescadores de Tamiahua" of an easier and simpler way. Optimizing a supply chain also helps improve customer experience and satisfaction, increase revenue and eliminate potential risks, aspects considered by customers as competitive advantages.

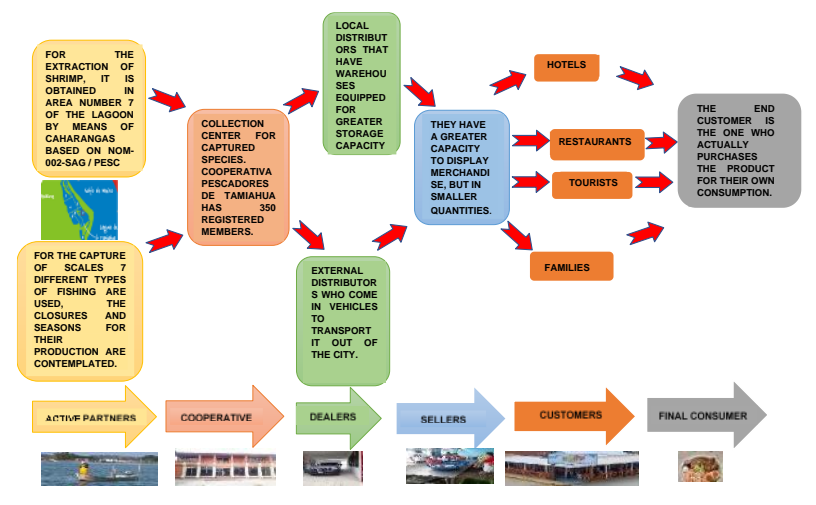

Figure 13 Supply chain

Source: self-made

\section{Acknowledgment}

This work was carried out thanks to the support of the Cooperative "Pescadores de Tamiahua".

\section{Conclusions}

The supply chain applied in the cooperative society "Pescadores de Tamihua" helps greatly to identify the set of activities, facilities, and means of distribution and sale of the product as a whole. This ranges from the extraction and capture of the species, their subsequent transportation to the collection centers, the storage and conservation process for their delivery to the final consumer. The supply chain involves all the essential operations for the product to reach the end customer in optimal conditions, in this way better customer service is achieved, this guarantees the growth and profitability of the business in general.

\section{References}

Agreement by which the similar one is modified by which the formats of the procedures in charge of the National Service of Health, Safety and Agrifood quality and of the National Commission of Aquaculture and Fisheries, decentralized administrative bodies of the Secretary of Agriculture are disclosed, Livestock, Rural Development, Fisheries and Food, indicated, published on August 28, 2015. Retrieved on August 16, 2021, from http://www.dof.gob.mx/nota_detalle_popup.ph $\mathrm{p}$ ? codigo $=5409964$

Álvarez S., C. y S. Gómez A., 2000. Listado de la fauna de copépodos (crustácea) de las lagunas costeras de Veracruz, México. Hidrobiología (10): 161-168. 
Álvarez Vela Ahime Cristina. Análisis de las pesquerías de la Laguna de Tamiahua, México: aplicando un enfoque espacio-temporal. Instituto de Ciencias Marinas y Pesquerías. Universidad Veracruzana, Boca del Rio, Veracruz. 2009.

Arias-Arias P. (Compilador). 1988. Artes y métodos de pesca en aguas continentales de América Latina. Organización de las Naciones Unidas para la Agricultura y la Alimentación. COPESCAL Doc Ocas. (4):178 pp.

Arzate A.E. 1991. Situación actual de la pesquería de las jaibas Callinectes sapidus y Callinectes rathbunae en Tamaulipas, 1987/89. Instituto Nacional de la Pesca. Centro Regional de Investigaciones Pesqueras. Tampico, Tamaulipas (inédito). Citado en: Instituto Nacional de la Pesca (INP)- Secretaría de Agricultura, Ganadería, Desarrollo Rural, Pesca y Alimentación (SAGARPA). 2006. Sustentabilidad y pesca responsable en México, evaluación y manejo. México. P. 560.

Consejo nacional de evaluación de la política de Desarrollo social (CONEVAL), 2017.

Diario Oficial de la Federación (D.O.F.). 1997. Aviso donde se da a conocer la autorización para utilizar charangas como equipos de pesca para la captura de camarón en los sistemas lagunarios estuarinos de Tamaulipas y del norte de Veracruz. Secretaría de Medio Ambiente, Recursos Naturales y Pesca. Única sección. México. 21 de noviembre de 1997.

Diario Oficial de la Federación (D.O.F.). 2006. Acuerdo mediante el cual se aprueba la actualización de la Carta Nacional Pesquera. Secretaría de Medio Ambiente y Recursos Naturales. Primera Sección. México. August 25, 2006.

Gordillo Morales Giberth y Cruz Paredes Leticia. Ficha informativa de los humedales de Ramsar (FIR). Consejo Estatal de la Protección al Ambiente. Gobierno del Estado de Veracruz. 2005.
Gómez Montoya Rodrigo Andrés, Zuluaga Mazo Abdul, Ceballos Atehourtua Nancy Patricia, Palacio Jiménez David. Gestión de la cadena de suministros y productividad en la literatura científica. I+D Revista de Investigaciones. ISSN 2256-1676 / ISSN en línea 2539-519X. Volumen 4 Numero 2 JulioDiciembre de 2019 pp. 34-44

Instituto Nacional de la Pesca (INP). 2000. Catálogo de los sistemas de captura de las principales pesquerías comerciales. Dirección General de Investigación y Desarrollo Tecnológico Pesquero. México, D.F. 139 pp.

Jiménez Sánchez José Elías, Hernández García Salvador. Marco Conceptual de la cadena de suministro: un nuevo enfoque logístico. Secretaria de Comunicaciones y Transportes Instituto Mexicano del Transporte. Publicación Técnica No. 2015. Sanfadila, Qro. 2002.

Ley General de Sociedades Cooperativas, artículo 2. 2018

Manrique Nugent, Manuel Alberto Luis; Teves Quispe, Julia; Taco Llave, Armando Marcelino; Flores Morales, Jorge Alberto; Gestion de cadena de sumnistro: una mirada desde la perspectiva teórica. Revista Venezolana de Gerencia, Vol. 24. Numero 88, Universidad de Zulia, Perú. 2019.

Rivera Vidal, Pamela (2021). Una breve aproximación a la Gobernanza Ambiental como eje de la Sustentabilidad. Meio Ambiente (Brasil), Vol 2, Número 5; 118-127 (2020).

Secretaria de Agricultura, Ganadería, Desarrollo Rural, Pesca y Alimentación. Comisión Nacional de Acuacultura y Pesca. Retrieved on August 16, 2021, from: https://www.gob.mx/c ms/uploads/attachment/file/130329/FF-

CONAPESCA-004_aviso_arribo_menores.pdf

Secretaria de Agricultura, Ganadería, Desarrollo Rural, Pesca y Alimentación. Comisión Nacional de Acuacultura y Pesca. Retrieved on August 16, 2021, from: https://www.gob.mx/cms/uploads/attachment/fi le/130327/FF-CONAPESCA-

005_aviso_arribo_mayores.pdf 
Watson, R. Revenga, C. Kura, Y. Fishing gear associated with global marine catches I.

Database development. Elsevier, Fisher Research 79 (2006) 97-102. 